\title{
Implementasi Istiwa'ani dalam Pemrograman Aplikasi Berbasis Android
}

\author{
Implementation of Istiwa'ani in Android Based App
}

\author{
Muhammad Faishol Amin \\ Universitas Islam Negeri Walisongo, Jl. Prof. Dr. Hamka (Kampus III), Ngaliyan. \\ Telp/Fax (024) 7601291, Semarang, Kode Pos 50185 \\ Program Magister Ilmu Falak, UIN Walisongo, Semarang. \\ E-mail: faisholamin2301@gmail.com
}

\begin{abstract}
Abstrak
Istiwaaini adalah salah satu perangkat yang bisa digunakan untuk menenukan arah kiblat. Dengan konsep yang sederhana Istiwaaini mampu menghasilkan arah kiblat dengan akurasi yang tinggi. Dalam penelitian ini penulis berusaha untuk mengembangkan konsep Istiwa'aini ke perkembangan yang lebih modern yaitu penerapan ke dalam pemrograman aplikasi berbasis android, salah satu sistem operasi yang sangat terkenal dan banyak digunakan saat ini. Penelitian bersifat kualitatif dengan menggunakan pendekatan science engineering, dengan data utama dari konsep perhitungan dan pengukuran Istiwa'aini, dan dilakukan dengan menggunakan sarana software Android Studio 3.0. Aplikasi Istiwa' Mobile merupakan hasil dari penelitian ini. Aplikasi ini mampu menyederhanakan semua konsep Istiwa'aini, dari tahap pencarian data, input, proses, pengukuran dan penyajian hasil, dikemas dengan sekali tekan (one click). Aplikasi ini juga dirancang dengan tampilan yang sederhana sehingga mudah untuk dioperasikan. Untuk akurasi dari Istiwa' Mobile dalam pengukuran arah kiblat pun tidak bergeser, tetap dalam taraf akurat $( \pm 3$ '). Hal ini dibuktikan dengan uji akurasi yang dilakukan oleh penulis dengan membandingkan dengan metode rashdul kiblat global. Dari hal tersebut maka dapat ditarik kesimpulan bahwa Istiwa' Mobile dapat dijadikan sebagai sarana baru untuk menentukan arah kiblat dengan cara lebih sederhana dan cocok semua orang, baik kalangan ahli, maupun kalangan awam.
\end{abstract}

Kata Kunci-Istiwa'aini, Android, Istiwa' Mobile

\begin{abstract}
Istiwaaini is one of the tools that can be used to find the direction of Qibla. With a simple concept, Istiwaaini able to produce Qibla direction with high accuracy. In this study the author seeks to develop the concept of Istiwa'aini to a more modern development that is the application programming android based, one of the operating system is very famous and widely used today. This research is qualitative by using science engineering approach, with main data from calculation and measurement concept of Istiwa'aini, and done by usng Android Studio 3.0 software. Istiwa' Mobile App is the result of this research. This application is able to simplify all the concept of Istiwa'aini, from the stage of data search, input, process, measurement and presentation of results, packed with an one click. This app is also designed with a simple display that is easy to operate. For the accuracy of Istiwa' Mobile in measuring the direction of the Qibla did not shift, remained in an accurate level ( \pm 3'). This is evidenced by the acuracy test conducted by the author by comparing with the global rashdul Qibla method. From this it can be concluded that Istiwa 'Mobile can be used as a new tool to determine the direction of Qiblah in a more simple and suitable way for all people, both the experts or the laity.
\end{abstract}

Keywords_Istiwa'aini, Android, Istiwa' Mobile 


\section{PENDAHULUAN}

Menghadap ke arah kiblat adalah merupakan salah satu syarat sahnya ibadah salat. Mendapatkan arah kiblat yang benar (benar-benar ke arah Kakbah) adalah suatu kewajiban bagi setiap muslim yang akan menjalankan ibadah salat [1].

Metode yang digunakan dalam menentukan arah kiblat bermacam-macam, baik itu metode dalam perhitungan maupun metode dalam pengukuran arah kiblat. Dalam perhitungan/hisab arah kiblat ada tiga metode yang dapat dipakai, yaitu teori Trigonometri Bola, teori Geodesi, dan teori Navigasi [2]. Sementara itu untuk pengukuran arah kibat sendiri bisa dilakukan dengan dua cara, yaitu dengan memakai azimut kiblat, atau rashdul kiblat. Alat yang digunakan dalam pengukuran arah kiblat pun bermacam-macam, seperti kompas, astrolabe, rubu' mujayyab, theodolite dan lain-lain [3].

Selain alat-alat diatas, ada satu alat lagi yang tergolong sangat akurat, dan mempunyai metode pengukuran yang sangat sederhana, sangat berbeda dengan alat-alat yang disebutkan diatas, yang secara umum jika metodenya sederhana maka tingkat akurasinya lemah, dan jika metodenya rumit maka alat tersebut memiliki akurasi yang tinggi. Alat tersebut adalah Istiwa'aini.

Istiwa'aini diciptakan oleh salah satu dosen di Universitas Islam Negeri Walisongo, yaitu Slamet Hambali. Dengan berdasar pada sistem kerja theodolite, ia mampu menyederhanakan sistem theodolite yang cukup rumit dan menciptakan alat baru yang sangat membantu dalam penentuan arah kiblat. Alat yang diciptakan oleh Slamet Hambali itu juga telah diuji tingkat keakurasiannya, dan selalu menghasilkan arah kiblat yang sangat akurat [4].

Seiring perkembangan ilmu pengetahuan dan teknologi yang semakin maju, kini ilmu falak mampu menghasilkan produk yang berbasis teknologi komputer. Para pecinta ilmu falak terdorong untuk mengaplikasikan ilmunya dalam bentuk program dan aplikasi berbasis android. Dari segi efektivitas kerja berbagai perhitungan rumit pun sudah dirangkai dalam bentuk aplikasi/software, sehingga dapat mempercepat waktu perhitungan. Salah satu basis program yang sangat familiar saat ini yaitu android.

Android merupakan salah satu wadah yang bisa dijadikan tempat untuk mengaplikasikan perhitungan falak, dengan bahasa pemrograman Java, perhitungan falak dapat diolah dengan akurasi yang tinggi, dan dengan bahasa pemrograman XML, tampilan dapat diatur sesuai kebutuhan. Selain itu dalam android sendiri ada berbagai fitur yang sangat mendukung kebutuhan ilmu falak seperti adanya internet time, GPS dan sensor proximity [5]. Dalam penelitian kali ini, penulis berusaha mengaplikasikan Istiwa'ani dalam pemrograman berbasis android, baik dari segi perhitungan maupun pengukurannya.

\section{METODE PENELITIAN}

Penelitian ini merupakan penelitian kualitatif dengan pendekatan science engineering. Memanfaatkan Istiwa'ani sebagai subjek implementasi dan sistem operasi android sebagai objek implementasi penelitian.

Data utama penulis ambil dari konsep Istiwa'aini, baik dari konsep perhitungan maupun dari konsep pengukuran. Konsep perhitungan menggunakan teori trigonometri bola dengan formula yang akan penulis sederhanakan dari formula asli Istiwa'aini. Sementara untuk konsep pengukuran, tetap menggunakan konsep asli Istiwa'aini. Hasil dari aplikasi yang dibuat dalam penelitian ini diberi nama Istiwa' Mobile. Penelitian ini 
juga memakai sarana Android Studio 3.0 sebagai software dalam pembuatan aplikasi Istiwa' Mobile.

Metode pemrograman dalam penelitian ini secara garis besar terdiri dari 2 tahap, yaitu tahap perancangan program dan tahap implementasi.

Perancangan Program dapat dilihat dari diagram berikut ini:

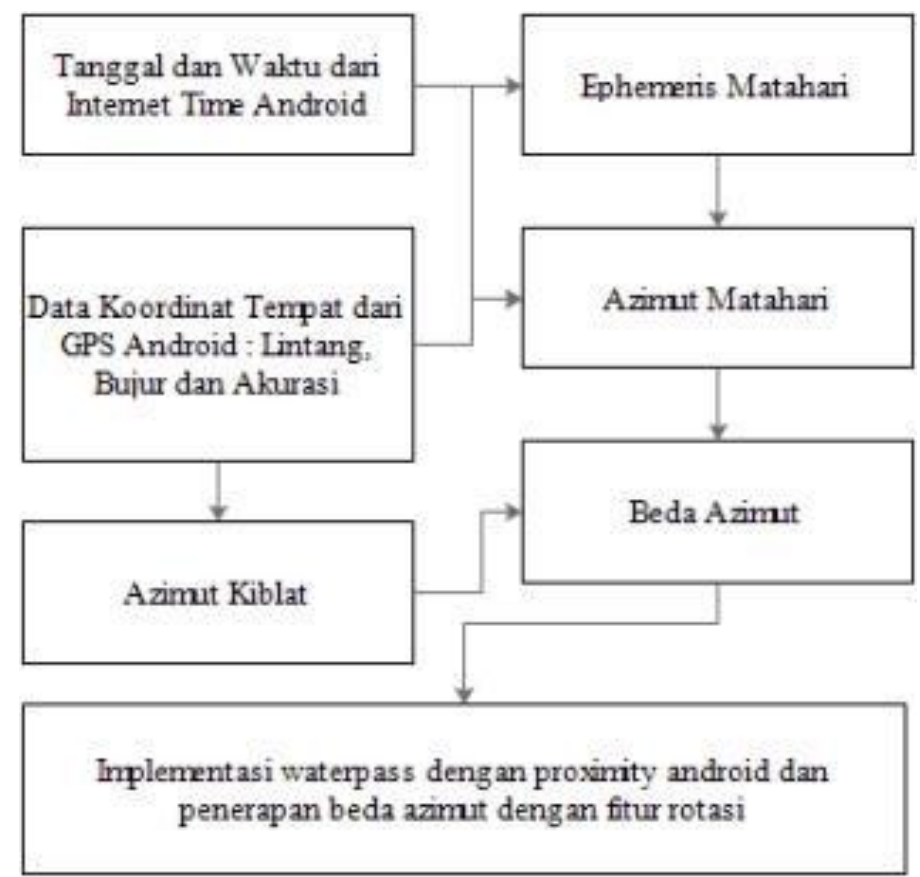

Gambar 1 Diagram Perancangan Program

\section{HASIL DAN PEMBAHASAN}

a. Teori Trigronometri Bola Istiwa'aini

Perhitungan arah kiblat yang dipakai dalam penggunaan Istiwa'aini terhimpun dalam satu aplikasi/software berbasis visual basic, yang dibuat oleh murid dari Slamet Hambali. Teori yang digunakan dalam aplikasi tersebut yaitu teori trigonometri bola, baik dalam perhitungan azimut Matahari maupun perhitungan azimut kiblat.

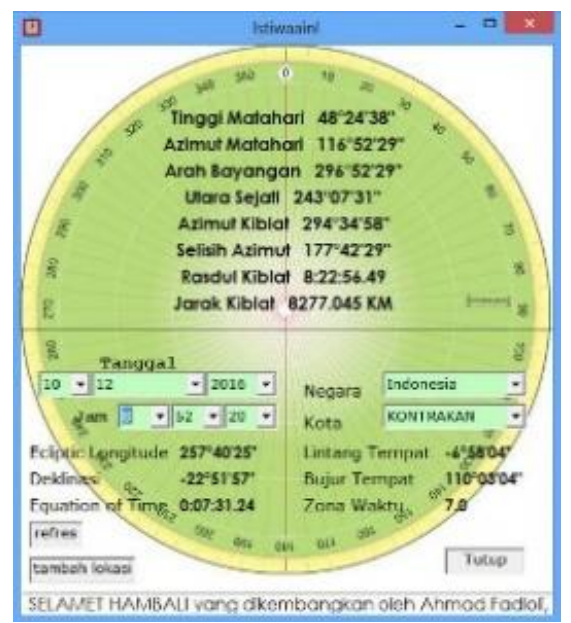

Gambar 2 Aplikasi Visual Basic Istiwa'aini 
Konsep yang dipakai dalam pengukuran sangat sederhana. Istiwa'aini memakai konsep bayangan arah Matahari yang diselisihkan dengan arah kiblat, jadi untuk mencari arah kiblat harus terlebih dahulu mencari arah Matahari, lalu hasil dari arah tersebut diimplementasikan saat pengukuran dengan Istiwa' aini.

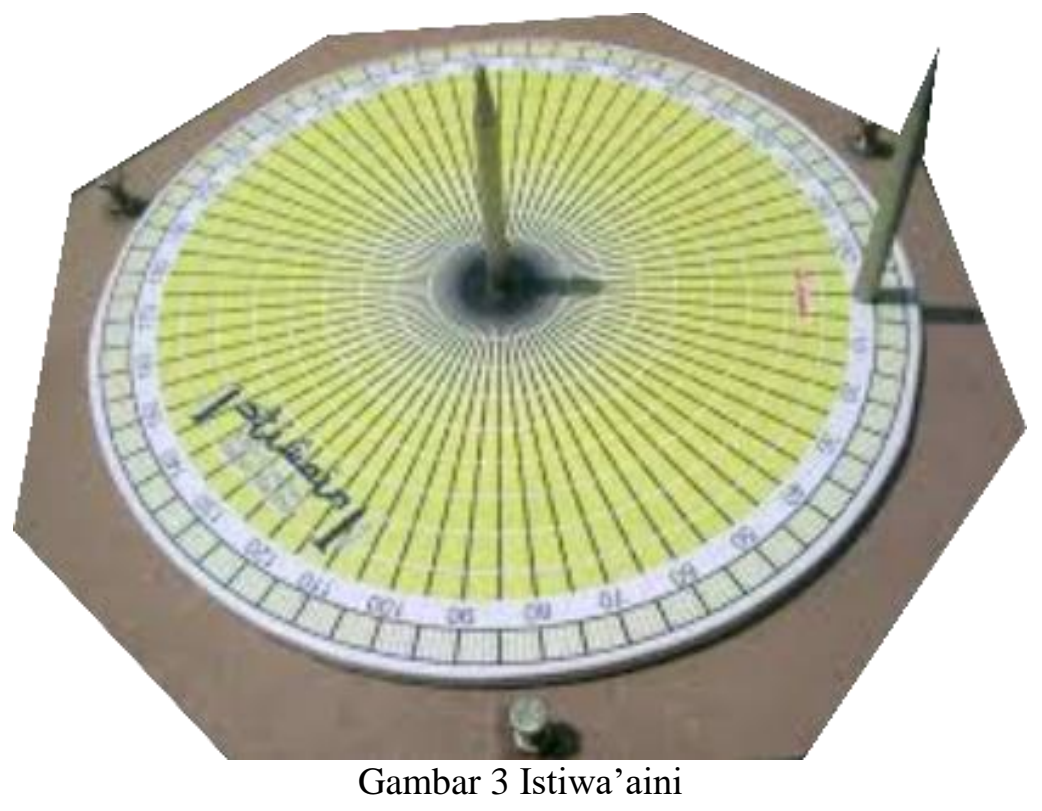

Perhitungan azimut Matahari dan azimut kiblat dalam trigonometri bola dapat dilihat dari keterangan berikut [6]:

1. Menghitung arah kiblat dan azimut kiblat.

- Arah kiblat dapat dihitung dengan rumus sederhana yaitu :

Cotan $B=\tan \varphi^{\mathrm{k}} \cdot \cos \varphi^{\mathrm{x}} \div \sin \mathrm{C}-\sin \varphi^{\mathrm{x}} \div \tan \mathrm{C}(1)$

- Menghitung azimut kiblat:

- $\quad$ Jika B = UT $(+)$, maka azimut kiblat $=\mathrm{B}$

- $\quad$ Jika B=ST (-), maka azimuth kiblat $=180+B$

- $\quad$ Jika $B=$ SB (-), maka azimut kiblat $=180-\mathrm{B}$

- $\quad$ Jika B= UB (+), maka azimut kiblat $=360-\mathrm{B}(2)$

2. Menghitung sudut waktu, arah dan azimut Matahari.

- Sudut waktu Matahari dapat dicari dengan rumus:

$$
\mathrm{t}=\left(\mathrm{LMT}+\mathrm{e}-\left(\lambda^{\mathrm{L}}-\lambda^{\mathrm{x}}\right) \div 15-12\right) .15(3)
$$

- Menghitung arah Matahari dengan rumus:

$\operatorname{Cotan} A=\tan \delta^{m} \cdot \cos \varphi^{\mathrm{x}} \div \sin \mathrm{t}-\sin \varphi^{\mathrm{x}} \div \tan \mathrm{t}(4)$

- Menghitung azimut Matahari

- $\quad$ Jika A = UT (+), maka azimut Matahari $=\mathrm{A}$

- $\quad$ Jika A=ST (-), maka azimuth Matahari $=180+\mathrm{A}$

- Jika A=SB (-), maka azimut Matahari = 180-A

- $\quad$ Jika A=UB (+), maka azimut Matahari=360-A (5)

3. Menghitungsudut kiblat dari bayangan Matahari $(\mathrm{Q})$, dengan diupayakan supaya besar sudut $Q$ tidak lebih dari $90^{\circ}$, sehingga rumus untuk $Q$ yaitu:

$$
\mathrm{Q}=\text { azimut kiblat }- \text { azimut Matahari (6) }
$$


Untuk rumus A dan B penulis sederhanakan, sehingga mempunyai logika pencarian kiblat yang lebih sederhana, hal ini diterapkan untuk mempermudah dalam pengaplikasian ke bahasa program:

$$
\begin{aligned}
& C \operatorname{Cotan} B=\tan \varphi^{\mathrm{k}} \cdot \cos \varphi^{\mathrm{x}} \div \sin \mathrm{C}-\sin \varphi^{\mathrm{x}} \div \tan \mathrm{C}(7) \\
& \operatorname{Cotan} \mathrm{A}=\tan \delta^{\mathrm{m}} \cdot \cos \varphi^{\mathrm{x}} \div \sin \mathrm{t}-\sin \varphi^{\mathrm{x}} \div \tan \mathrm{t}(8)
\end{aligned}
$$

Untuk mencari azimut kiblat dengan logika :

- $\quad$ Jika $\mathrm{C}<0$ dan $\mathrm{C}<-180$, maka azimut kiblat $=90+\mathrm{B}$

- Jka tidak maka azimut kiblat $=270+$ B. (8)

Untuk mencari azimut Matahari dengan logika:

- Jika $\mathrm{t}<0$ dan $\mathrm{t}<-180$, maka azimut Matahari $=90+\mathrm{A}$

- Jika tidak maka azimutMatahari $=270+$ A. (9)

Rumus tersebut bisa diolah dengan algoritma aritmatika (penambahan, pengurangan, perkalian dan pembagian) dan trigonometri (sin, cos, tan, atan) yang ada pada bahasa pemrograman java dengan cukup mudah [7].

b. Fitur Android yang digunakan dalam Istiwa' Mobile

Fitur yang tertanam dalam android yang dipakai untuk perancangan aplikasi dalam penelitian ini ada empat fitur, yaitu GPS, internet time, proximity dan image rotation. GPS digunakan untuk perhitungan inti azimut kiblat dan azimut Matahari, data yang diperlukan dari GPS yaitu lintang tempat, bujur tempat dan akurasi GPS. Akurasi dalam hal ini digunakan untuk mencari tingkat keakuratan GPS dalam mengolah data koordinat lintang dan bujur tempat [8]. Fitur ini mempermudah para pegiat falak untuk perhitungan/pengukuran dalam ilmu falak. Biasanya para pegiat ilmu falak selalu memakai GPS handheld saat praktek lapangan, yang sulit dicari dan harganya juga cukup mahal.

Internet time juga akan sangat membantu dalam pembuatan aplikasi, selain mempermudah dalam hal input data, data yang dihasilkan juga cukup akurat karena selalu tersinkron dengan server ntp. Jadi waktu yang diperoleh merupakan atomic time [9]. Hal ini sangat berbeda jika dibandingkan dengan jam digital atau jam analog yang dimiliki oleh pengguna, yang jarang sekali tersinkron dengan atomic time.

Waktu yang diperoleh dari internet time akan diolah menjadi data ephemeris Matahari, yang akan dipakai dalam perhitungan yaitu data deklinasi $(\delta)$ dan equation of time (e). data yang dihasilkan akan berjalan terus menerus menyesuaikan waktu yang telah didapatkan sebelumnya. Sehingga perhitungan azimut Matahari akan berjalan secara real time.

Sensor proximity juga dimanfaatkan oleh penulis dalam pembuatan aplikasi ini. Dengan fitur ini, sensor proximity dapat diolah dan dijadikan alat waterpass, untuk memperoleh kedataran suatu bidang. Dalam prakteknya, para pegiat falak selalu memakai waterpass untuk menjaga keakurasian hasil pengukuran arah kiblat.

Fitur rotasi dalam pemograman bahasa Java menjadi fitur yang paling utama yang diangkat penulis untuk menjadi pengganti dari perangkat Istiwa'aini. Dengan menggunakan rotasi, arah yang diperoleh dari bayangan yang diterapkan di sisi samping kanan/kiri android bisa diputar dan diselisihkan dengan arah kiblat melalui gambar panah yang ada di tengah layar, sehingga gambar panah akan mengarah ke arah kiblat. 


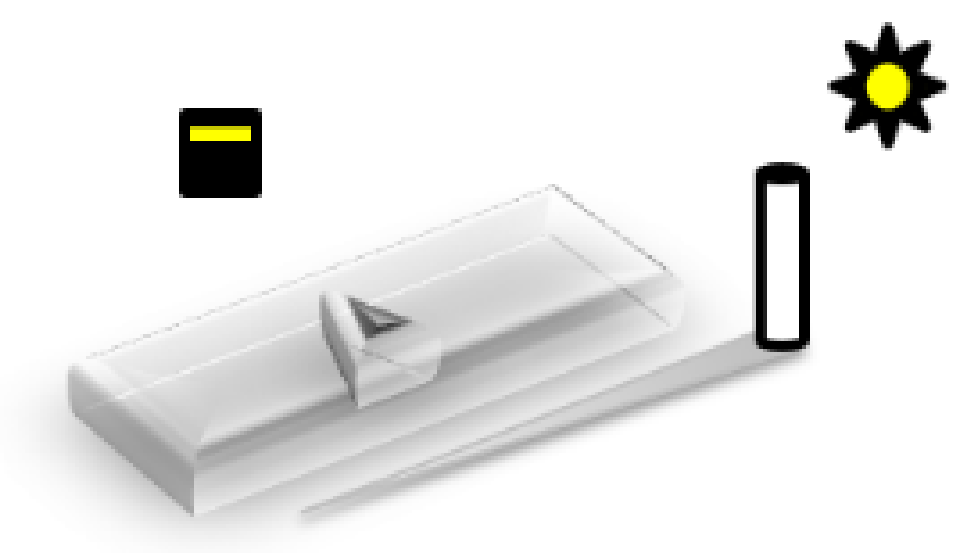

Gambar 4 Ilustrasi pemakaian Istiwa’ Mobile

c. Implementasi Istiwa'aini dalam Istiwa' Mobile

Penulis telah berhasil mengimplentasikan perhitungan dan pengukuran Istiwa'aini ke dalam program berbasis android. Aplikasi ini terdiri dari tiga activity, yaitu activity awal, activity inti (Istiwa' Mobile) dan activity kompas (alternatif).

Tampilan awal (activity pertama) berisi data koordinat yang diperoleh dari GPS (GPS, Internet/Wi-fi), dalam activity ini juga telah dihitung nilai azimut kiblat di koordinat yang telah diperoleh. Kemudian data tersebut ditampilkan di activity ini dan dikirimkan ke dua activity yang lain.
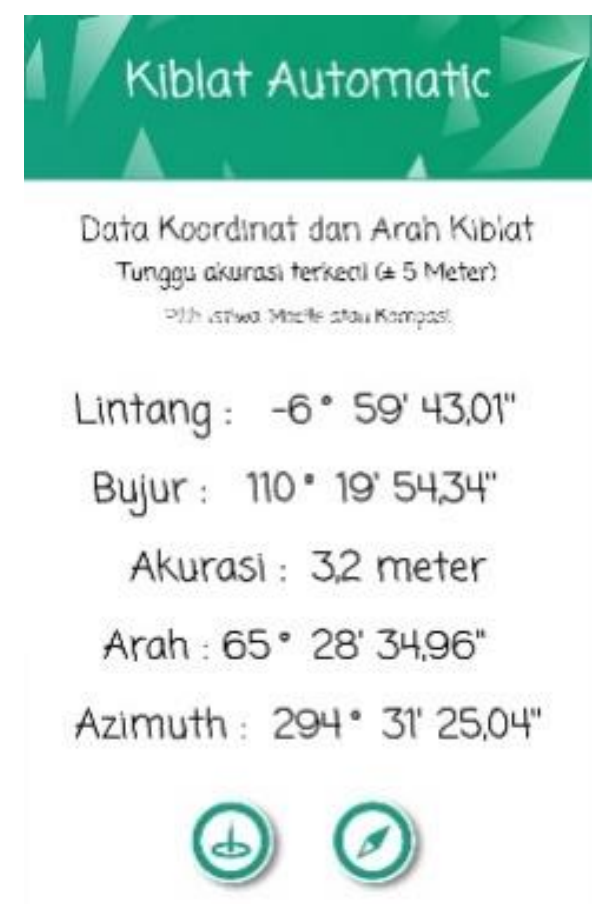

Gambar 5 Tampilan awal Istiwa’ Mobile

Tampilan Istiwa' Mobile (activity inti) berisi implementasi Istiwa'aini. Terlebih dahulu data koordinat dan nilai azimut diambil dari activity awal, kemudian data tersebut diproses sehingga menghasilkan data ephemeris Matahari (deklinasi dan equation of time), azimut Matahari, dan sudut beda azimut. Selanjutnya diterapkan proses rotasi gambar sesuai dengan besar beda azimut. 


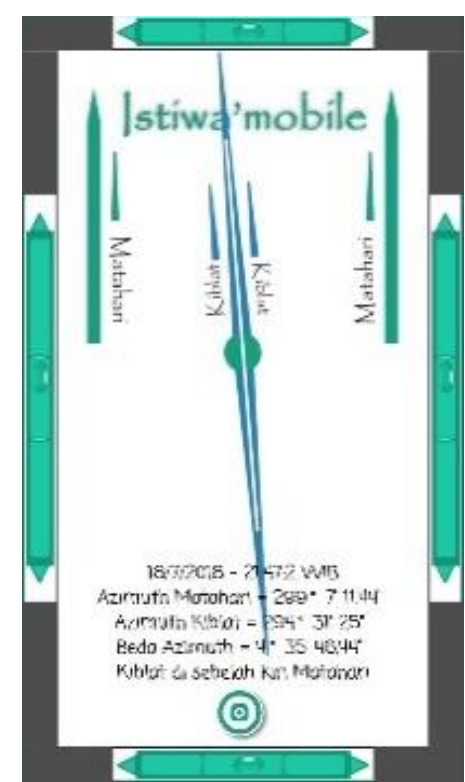

Gambar 6 Tampilan inti Istiwa’ Mobile

Tampilan Kompas berisi penentuan arah kiblat dengan kompas, fitur ini dibuat sebagai alternatif jika penentuan arah kiblat dengan activity inti tidak bisa dilakukan akibat jika tidak ada Matahari (mendung/malam hari). Activity ini juga memanfaatkan satu fitur lagi yang tertanam dalam android, yaitu sensor kompas.

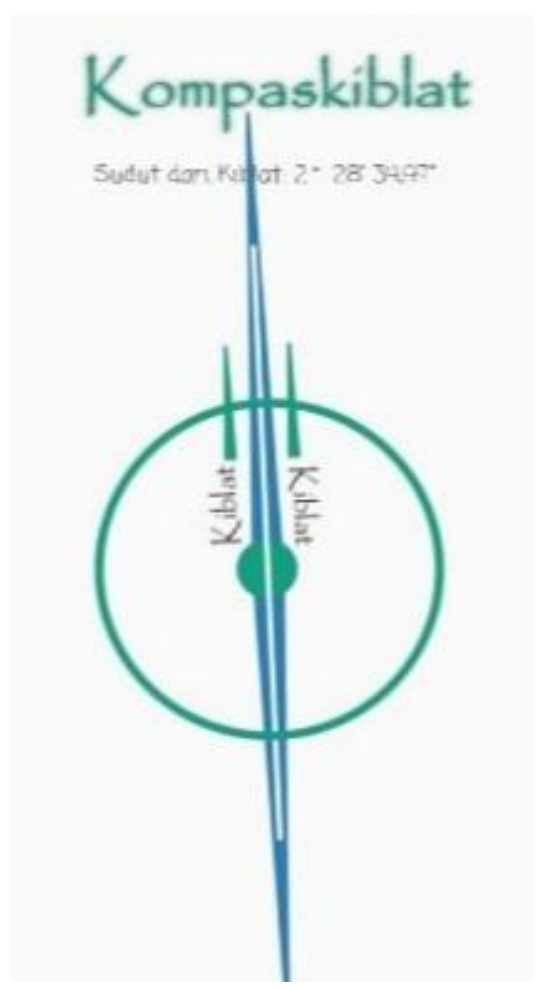

Gambar 7 Tampilan Kompas sebagai alternatif Istiwa’ Mobile

d. Uji Akurasi Istiwa' Mobile

Dalam penelitian ini penulis berusaha menguji Istiwa' Mobile dengan membandingkannya dengan metode rashdul kiblat global, salah satu metode yang 
sangat akurat dan mudah. Karena keakuratan metode rashdul kiblat global ini, metode ini biasa dipakai para pegiat falak untuk mengecek ulang kiblat masjid-masjid dan musala-musala. Rashdul kiblat global terjadi 2 kali dalam setahun yaitu tanggal 27/28 Mei pukul 16:18 WIB dan tanggal 15/16 Juli pukul 16:27 WIB. Pada saat itu Matahari akan tepat berada diatas Kakbah, maka dari itu bayangan yang dihasilkan akan selalu menghadap kiblat.

Jika dilihat dari azimut, nilai azimut Matahari yang dihasilkan pun seharusnya sama dengan nilai azimut kiblat.
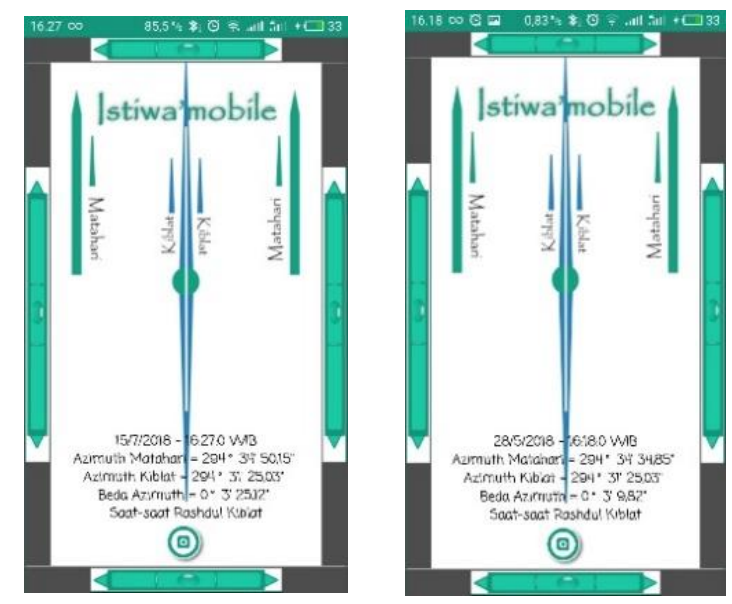

Gambar 8 Uji Validitas Istiwa’ Mobile (15 Juli dan 28 Mei)

Dari gambar diatas dapat diketahui bahwa arah kiblat/panah yang mengarah, menunjuk ke arah atas, hal ini menandakan bahwa arah dari kiblat sama dengan arah dari sinar Matahari. Dan jika dilihat dari selisih atau tingkat keakurasian dari Istiwa' Mobile, termasuk kedalam tingkat yang akurat. Pada tanggal 15 Juli terdapat selisih hanya sebesar $0^{\circ} 3^{\prime} 25,12$ ", sementara untuk tanggal 28 Mei selisihnya hanya sebesar 0 3' 9,92'.

\section{KESIMPULAN}

- Konsep penentuan arah kiblat dengan menggunakan Istiwa'aini dapat disederhanakan dengan menggunakan algoritma pemrograman aplikasi berbasis android.

- Simplifikasi dapat dilakukan disemua tahap, mulai dari tahap pencarian data, input, proses, pengukuran dan penyajian hasil.

- Hasil yang didapatkan dalam implementasi Istiwa'aini tidak bergeser, tetap dalam tingkat akurat $\left( \pm 3^{\prime}\right)$.

\section{SARAN}

- Istiwa' Mobile dapat dilakukan pengembangan lagi jika memakai fitur kamera dan sensor gyroscope, sehingga arah kiblat yang dihasilkan akan langsung ada di kamera.

- Magnetic declination juga dapat ditambahkan dalam fitur kompas kiblat, sehingga mengurangi tingkat kesalahan yang dihasilkan. 


\section{DAFTAR PUSTAKA}

[1] Slamet Hambali, 2014. Menguji Keakuratan Hasil Pengukuran Arah Kiblat Menggunakan Istiwaaini Karya Slamet Hambali. Laporan Hasil Penelitian Individual IAIN Walisongo Semarang, hlm. V

[2] Ahmad Izzuddin, 2012. Kajian terhadap Metode-metode Penentuan Arah Kiblat dan Akurasinya. Jakarta: Kementrian Agama Republik Indonesia. hlm.88-120.

[3] Ahmad Izzuddin, 2012. Kajian terhadap Metode-metode Penentuan Arah Kiblat dan Akurasinya. Jakarta: Kementrian Agama Republik Indonesia. hlm.67-83.

[4] Slamet Hambali, 2014. Menguji Keakuratan Hasil Pengukuran Arah Kiblat Menggunakan Istiwaaini Karya Slamet Hambali. Laporan Hasil Penelitian Individual IAIN Walisongo Semarang, hlm.111.

[5] Ivan Michael Siregar, 2011. Android Source Code. Yogyakarta: Penerbit Gava Media. hlm.122-152.

[6] Ahmad Izzuddin, 2002. Ilmu Falak Praktis, Jakarta: Kementrian Agama RI. hlm.72.

[7] Abdul Kadir, 2012. Algoritma dan Pemrograman Menggunakan Java. Yogyakarta: Andi Offset. hlm.86.

[8] Ahmad Fali Oklilas, dkk. 2015. Akurasi Pembacaan GPS pada Android untuk Location Based Service (Studi Kasus :Informasi Lokasi SMA di Palembang),Vol.4 No.1. hlm 1-5.

[9] National Physical Laboratory, 2007. A User's Guide to The NPL Internet Time Service, United Kingdom : NP Laboratory. hlm.2. 